\title{
A Review of Chimeric Antigen Receptor T-Cell Therapy for Myeloma and Lymphoma
}

This article was published in the following Dove Press journal: OncoTargets and Therapy

\author{
Shebli Atrash (iD) \\ Tamara K Moyo ${ }^{2}$ \\ 'Plasma Cell Disorders Division, \\ Department of Hematologic Oncology \& \\ Blood Disorders, Levine Cancer \\ Institute/Atrium Health, Charlotte, NC, \\ USA; ${ }^{2}$ Lymphoma Division, Department \\ of Hematologic Oncology \& Blood \\ Disorders, Levine Cancer Institute/ \\ Atrium Health, Charlotte, NC, USA
}

\begin{abstract}
Collectively, hematological malignancies account for the fourth most common malignancy. Myeloma and lymphoma are the most common types of hematological malignancies. Unfortunately, the management of refractory myeloma and lymphoma remains challenging. The discovery of new immunological therapies, namely chimeric antigen receptors $\mathrm{T}$ cells (CAR-T), outlined unprecedented $\mathrm{B}$ cell malignancies results. In this context, the CAR-T-based approach has led to the proliferation of many clinical studies. In this review, we will deal with the CAR-T structure, and we will summarize the primary clinical studies assessing the risks and benefits of CAR-T cell therapy. We will also deal with the adverse events and management of cytokine release syndromes/immune effector cellassociated neurotoxicity syndrome (ICANS). Subsequently, we will review potential future improvements to overcome refractoriness and improve expansion while decreasing CAR-T's off-target effects. The advances in the CAR-T platform represent a step forward with promising unlimited future possibilities that made it a paradigm-shifting for the management of B cell malignancies.
\end{abstract}

Keywords: multiple myeloma, relapsed, refractory, treatment, chimeric antigen receptor, $\mathrm{T}$ cells, cytokine release syndrome, lymphoma, leukemia

\section{Introduction}

Hematological malignancies are collectively the fourth most common of all cancers in the United States. ${ }^{1}$ Despite the major leaps forward in treatment options, relapsed and refractory disease remains a challenge. Progress for hematological malignancies has been exceptionally rapid due to improvements in treatment protocols, including the development of targeted therapies. For example, the multiple myeloma (MM) 5-year relative survival rate increased from $25 \%$ in the 1970 s to $56 \%$ in 2012 , and close to $75 \%$ in US-academic centers. ${ }^{1,2}$ However, it is estimated that every 9 minutes, someone in the US dies from a hematological malignancy. ${ }^{1}$ When chemotherapeutic options fail, novel immunologic approaches are needed.

During initial tumor progression, tumor cells escape immune recognition and become less immunogenic in a process termed "cancer immune editing." 3 The role of immunotherapy in stimulating the immune response against cancer cells might represent the future of hematological malignancy treatments. A new treatment concept for genetically engineered $\mathrm{T}$ cell immunotherapy is now available. This socalled chimeric antigen receptor CAR-T cell therapy leads to considerable overall response rates, even in highly pretreated and refractory hematological malignancies. Hence, the US Food and Drug Administration (FDA) granted the first breakthrough
Correspondence: Shebli Atrash Plasma Cell Disorders Division, Department of Hematologic Oncology \& Blood Disorders, Levine Cancer Institute/ Atrium Health, I02I Morehead Medical Drive, Charlotte, NC, 28204, USA

Email Shebli.atrash@Atriumhealth.org 
designation for a CD19-CAR-T cell therapy for patients with relapsed/refractory NHL in $2017 . .^{4}$ Also, another approval was granted for patients 25 or younger with relapsed/refractory B-cell acute lymphoblastic leukemia (B-ALL). Others followed this approval for relapsed refractory mantle cell lymphoma in 2020 and diffuse large B-cell lymphoma in 2021. ${ }^{5,6}$ More approvals are likely to follow 2021.

CAR-T consists of genetically modified cells either through transfection (DNA plasmid inclusion) or transduction (using viral vector), introducing a new antigen on the T-cell surface to enable cancer cell detection. Since its introduction, multiple methods for CAR-T production have developed. Transduction methods may use either a lentivirus or gamma-retro virus as vectors for genetic modification, whereas the transfection method could transfer the new genes to a T-cell without using a virus vector. Examples of transfection methods include Sleeping Beauty ${ }^{\circledR}$ or piggyBac ${ }^{\mathrm{TM}}$ methods. ${ }^{7,8}$

The end product is a new T-cell powered by a specific antibody directed against a selected antigen. One advantage of these CAR-T activities is that they do not depend on antigen HLA presentation. The CAR molecule consists of three parts: 1) an extracellular domain containing a single-chain fragment variable directed against a specifically targeted antigen and an antigen recognition site connected with a linker. The extracellular domain is then attached with a hinge to 2) a transmembrane domain, part of CD3, CD8, CD28 or FceRI, which is then connected to 3) an intracellular domain, consisting of the intracytoplasmic activating domain (CD28, CD27, CD134, CDB7, or CD3 ) with or without a second costimulatory factor (CD28, or 4-1BB). Figure 1.

CAR-Ts could be autologous or off-the-shelf allogenic, depending on the source. Autologous CAR-T is more frequently used because it has a simpler structure, and its clinical development started earlier. However, allogenic CAR-T is a more convenient off-the-shelf option. ${ }^{9,10}$ Due to GVHD concerns, allogenic CAR-Ts are usually supplemented with a suicidal gene or death receptor-like CD20, protease/protease inhibitor system, synthetic notch receptors, or a small molecule gated zeta chain associated protein kinase 70 (ZAP70) suicidal switch. ${ }^{9,10}$

\section{CAR-T Engineering Issues}

Several factors can influence CAR-T's overall outcomes and can be divided into CAR-T manufacturing factors and clinically related factors. First, CAR-T cell quality is assessed by color, presence of transgenes, number and percentage of T-cells and viable T-cells, CD4:CD8 ratio, the extent of expression of CAR on the cell surface, cytokine production, presence of bacterial endotoxins, the risk of insertional oncogenesis, presence of residual magnetic beads, and sterility. Secondly, clinical factors include immune-dependent cancer antigen selection, preferably cancer-specific antigen; CAR-T persistence in the patient; and the associated toxicity profile with cytokine release syndrome (CRS) and immune effector cell-associated neurotoxicity syndrome (ICANS). While CAR-T's goal is to direct the new T-cells against cancers, it should be noted that the off-target effect should always be considered. For example, persistent CAR-T against SLAM-F7 or Kappa light chain in multiple myeloma, theoretically, could lead to prolonged immune suppression, which in turn might offset the benefit of myeloma control. Similarly, B-cell aplasia is a concern for CD19 CAR-T treatment. ${ }^{11,12}$

Table 1 summarizes the currently available/proposed targets for myeloma and lymphoma with a list of potential off-target expressions. CD19 is the primary target for lymphoma clinical trials, whereas B-cell maturation antigen (BCMA) is the main target for myeloma. ${ }^{13}$ CD19 is a transmembrane protein expressed on the surface of normal and neoplastic B cells that modulates intracellular signaling pathways, including the B cell receptor signaling pathway that is dysregulated in many B-NHL types. ${ }^{14}$ BCMA supports survival and promotes cell growth and chemotherapy resistance. ${ }^{15}$ Hence as expected, expression of BCMA increases with progression from MGUS to active myeloma and is associated with worse outcomes. ${ }^{15}$ Many other targets could be exploited as alternative options for CAR-T in MM and lymphoma treatment. (Table 1).

Data from clinical trials are accumulating about each of those different targets. However, herein we will summarize the most clinically relevant results.

\section{CAR-T Cells in Clinical Trials for Lymphoma \\ CAR-T Cells for Diffuse Large B Cell Non-Hodgkin's Lymphoma}

Outcomes for patients with relapsed/refractory aggressive B cell non-Hodgkin lymphoma (B-NHL) are poor. The efficacy of salvage chemotherapy regimens for refractory diffuse large B cell lymphoma (DLBCL) is dismal, with response rates ranging from $20-31 \%$ and complete 


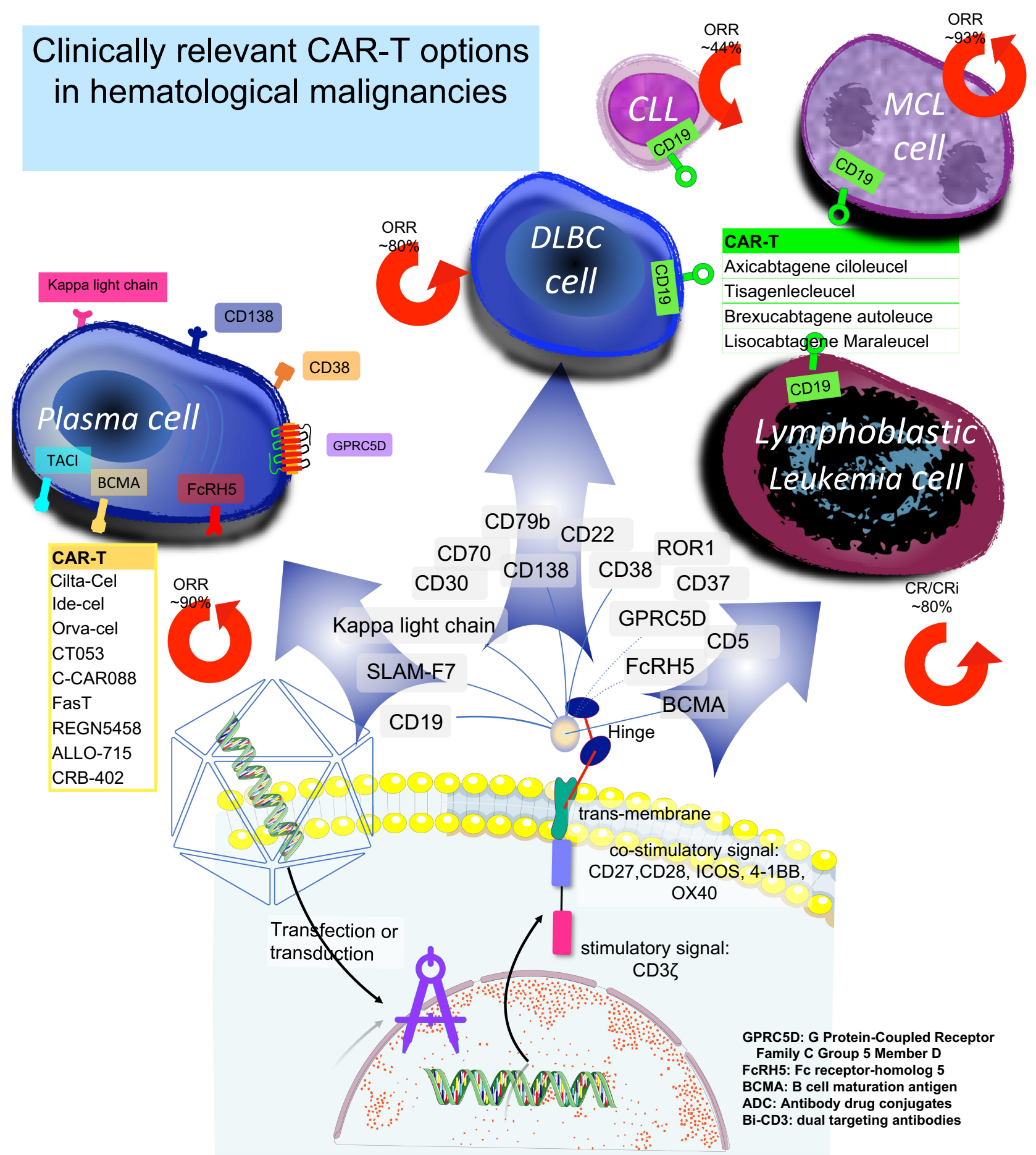

Figure I CAR-T cell use in hematological malignancies.

response rates $2-15 \% .{ }^{16}$ Overall survival for patients with relapsed/refractory DLBCL is estimated to be 6.3 months after salvage therapy initiation, with only $20 \%$ of patients alive at two years. ${ }^{16}$ Similarly, the overall survival of mantle cell lymphoma (MCL) patients who have failed front-line therapy and BTK inhibition is 2.9 months, only slightly improved to 5.8 months for patients fit for additional therapy. ${ }^{17}$ Patients with indolent B cell non-Hodgkin lymphoma enjoy a longer survival, but relapse is inevitable Responses and overall life expectancy are shorter with 
Table I CAR Antigens Being Examined in Hematological Malignancies

\begin{tabular}{|c|c|c|c|c|}
\hline Target & Indication & On Tumor Target & Off-Tumor & Refs \\
\hline BCMA & $\begin{array}{l}\text { Multiple myeloma } \\
\text { BCMA+ B cell } \\
\text { lymphomas and } \\
\text { leukemias }\end{array}$ & $\begin{array}{l}\text { Near universal expression by MM cells in } \\
\text { most patients }\end{array}$ & Plasmacytoid, DCs & {$[15,68,69]$} \\
\hline SLAMF7 & Multiple myeloma & Expression in $95 \%$ of $M M$ & $\begin{array}{l}\text { Plasma cells, NK cells, NK-like T cells, CD8+ } \\
\text { T cells }\end{array}$ & {$[29,70]$} \\
\hline CD38 & Multiple myeloma & Most MM 80-100\% & $\begin{array}{l}\text { Early B-cells, NK cells, activated T-cells, basophils, } \\
\text { monocytes, hematopoietic progenitors, DCs, cardiac } \\
\text { and smooth muscle cells, cornea, gut, pancreas }\end{array}$ & [7I-73] \\
\hline CDI38 & Multiple myeloma & Most MM cells in most patients $90-100 \%$ & Epithelial cells, pre-B-cells & {$[74]$} \\
\hline CD56 & Multiple myeloma & Strong expression in $70-90 \% \mathrm{MM}$ & Muscle cells, neurons, NK cells, NK-like T-cells & [75-77] \\
\hline CD74 & Multiple myeloma & $95 \%$ of plasma cells in $>50 \%$ of patients & $\begin{array}{l}\text { DCs, B-cells, DC, activated-T-cells, monocytes, } \\
\text { macrophages }\end{array}$ & {$[35,78]$} \\
\hline CD40 & Multiple myeloma & Variable expression most MM 70-100\% & Plasma cells, DCs, APCs & {$[36,79]$} \\
\hline $\begin{array}{l}\text { Kappa } \\
\text { Light Chain }\end{array}$ & $\begin{array}{l}\text { Multiple myeloma } \\
\text { FL, MZL, MCL }\end{array}$ & Expression in $35 \%$ of the MM & Clonogenic MM precursors, mature B-cells & {$[80,81]$} \\
\hline $\begin{array}{l}\text { Lewis } \\
\text { Antigen }\end{array}$ & Multiple myeloma & Expression in $52 \%$ of $\mathrm{MM}$ & Epithelial cells and granulocytes & {$[82]$} \\
\hline $\begin{array}{l}\text { NY-ESO } \\
- \text { I/LAGE-I }\end{array}$ & Multiple myeloma & $\begin{array}{l}\text { Expression in about } 34 \% \text { of the HLA-A2 } \\
\text { positive MM. }\end{array}$ & $\begin{array}{l}\text { Restricted expression to germ cells and malignant } \\
\text { tissues }\end{array}$ & {$[83,84]$} \\
\hline CDI9 & $\begin{array}{l}\text { Multiple myeloma } \\
\text { B-NHL, CLL, } \\
\text { B-ALL }\end{array}$ & $\begin{array}{l}\text { Expressed only on } 5 \% \text { of } \mathrm{MM} \text { cells } \\
\text { Nearly universal expression in B-NHL }\end{array}$ & Clonogenic MM precursors, pan-B-cell marker & {$[80,85]$} \\
\hline CD229 & Multiple myeloma & $\begin{array}{l}\text { Expressed in all plasma cell dyscrasias, } \\
\text { especially with plasma cells showing the } \\
\text { CD56+ aberrant phenotype. }\end{array}$ & Expressed on T and NK cells. & {$[86,87]$} \\
\hline NKG2D & Multiple myeloma & $\begin{array}{l}\text { NKG2D upregulated in response to DNA } \\
\text { damage, infection with certain pathogens, } \\
\text { and importantly, malignancies like MM. }\end{array}$ & $\begin{array}{l}\text { Present on NK cells, invariant NKT cells, } \gamma \delta \mathrm{T} \text { - } \\
\text { cells, CD8 T-cells, and a small fraction of CD4 } \\
\text { T-cells. }\end{array}$ & {$[88]$} \\
\hline APRIL & Multiple myeloma & $\begin{array}{l}\text { A proliferation-inducing ligand (APRIL) is } \\
\text { members of the tumor necrosis factor } \\
\text { (TNF) family. APRIL stimulates BCMA }\end{array}$ & B lymphocytes, fibroblasts. & {$[89,90]$} \\
\hline GPRC5D & Multiple myeloma & $\begin{array}{l}\text { A member of the } G \text { protein-coupled } \\
\text { receptor family }\end{array}$ & Hair follicles & [91] \\
\hline FcRH5 & Multiple myeloma & $\begin{array}{l}\text { A member of the immunoglobulin receptor } \\
\text { superfamily and the Fc-receptor like family. }\end{array}$ & $\begin{array}{l}\text { Epstein-Barr virus- transformed lymphocytes, } \\
\text { spleen, and the terminal ileum of the small intestine }\end{array}$ & [92] \\
\hline CD79b & B-NHL, B-ALL & Expressed on the surface of $2 / 3$ of $\mathrm{B}-\mathrm{NHL}$ & B lymphocytes & {$[93,94]$} \\
\hline CD20 & $\mathrm{B}-\mathrm{NHL}$ & $\begin{array}{l}\text { Expressed by } 90 \% \text { of B-NHL and } 40 \% \text { of } \\
\text { B-ALL }\end{array}$ & Pan-B cell marker, follicular dendritic cells & [95] \\
\hline
\end{tabular}


Table I (Continued).

\begin{tabular}{|c|c|c|c|c|}
\hline Target & Indication & On Tumor Target & Off-Tumor & Refs \\
\hline $\mathrm{CD} 22$ & $\begin{array}{l}\text { B-NHL, B-ALL, } \\
\text { CLL }\end{array}$ & Expressed by most B-NHL, B-ALL and CLL & Epithelioid histiocytes, B lymphocytes & {$[62,96]$} \\
\hline RORI & MCL, CLL, B-ALL & $\begin{array}{l}\text { Highly expressed in CLL, but less than } 10 \% \\
\text { expression in B-ALL }\end{array}$ & B-lymphocyte precursors & {$[97,98]$} \\
\hline $\mathrm{CD} 30$ & $\begin{array}{l}\text { Hodgkin } \\
\text { lymphoma, } \\
\text { B-NHL, T-NHL }\end{array}$ & $\begin{array}{l}\text { Highly expressed in } \mathrm{ALCL} \text { and classical } \\
\text { Hodgkin lymphoma; variable expression in } \\
\text { other PTCL and B-NHL }\end{array}$ & $\begin{array}{l}\text { Granulocytes, plasma cells, activated B, T ad NK } \\
\text { cells, monocytes }\end{array}$ & [37] \\
\hline CD70 & $\begin{array}{l}\text { B-NHL, AML, } \\
\text { MM, T-NHL }\end{array}$ & $\begin{array}{l}\text { Highly expressed in DLBCL, FL, LPL and } \\
\text { Hodgkin lymphoma; CLL and AML }\end{array}$ & $\begin{array}{l}\text { Activated B and T cells, thymic stromal cells, NK } \\
\text { cells, dendritic cells; Aberrantly overexpressed by } \\
\text { multiple solid tumors }\end{array}$ & [99] \\
\hline CD7 & $\begin{array}{l}\text { NK/T cell } \\
\text { lymphoma, } \\
\text { T-ALL, AML }\end{array}$ & $\begin{array}{l}\text { Highly expressed in T-ALL and most NK } \\
\text { cell lymphomas; Expressed in a subset of } \\
\text { myeloid malignancies }\end{array}$ & $\begin{array}{l}\text { T lymphocytes, NK cells, thymocytes; variably } \\
\text { expressed in monocytes, early myeloid cells, pre-B } \\
\text { cells }\end{array}$ & {$[100,101]$} \\
\hline CD4 & $\begin{array}{l}\text { PTCL, NOS, AITL, } \\
\text { ALCL, CTCL }\end{array}$ & $\begin{array}{l}\text { Expressed in many post-thymic } T \text { cell } \\
\text { lymphomas }\end{array}$ & $\begin{array}{l}\text { T helper cells, thymocytes, granulocytes, } \\
\text { macrophages, DC }\end{array}$ & {$[102]$} \\
\hline CD5 & $\begin{array}{l}\text { T-ALL, PTCL, } \\
\text { CTCL }\end{array}$ & $\begin{array}{l}\text { Uniformly expressed on T-ALL; Variable } \\
\text { expression in PTCL and CTCL }\end{array}$ & $\begin{array}{l}\text { Expressed on virtually all peripheral T lymphocytes, } \\
\text { thymocytes; }\end{array}$ & {$[66,103]$} \\
\hline $\begin{array}{l}\text { TCR } \\
(\mathrm{TRBCI})\end{array}$ & $\begin{array}{l}\text { PTCL, NOS, } \\
\text { AITL, ALCL }\end{array}$ & $\begin{array}{l}>95 \% \text { of } \mathrm{PTCL} \text { homogeneously express } \\
\text { either TRBCI or TRBC2 }\end{array}$ & T lymphocytes & {$[104,105]$} \\
\hline CD37 & $\begin{array}{l}\text { B-NHL, CLL, } \\
\text { PTCL, CTCL, } \\
\text { T-PLL }\end{array}$ & $\begin{array}{l}\text { Highly expressed in both B-NHL and } \\
\mathrm{T}-\mathrm{NHL}\end{array}$ & Expressed on non-neoplastic B and T cells & [102] \\
\hline
\end{tabular}

Abbreviations: BCMA, B-cell maturation antigen; DC, dendritic cells; B-ALL, B cell acute lymphoblastic leukemia; CLL, chronic lymphocytic leukemia; B-NHL, B cell nonHodgkin lymphoma; NK, Natural Killer; APC, antigen presenting cell; MM, multiple myeloma; RORI, receptor tyrosine kinase-like orphan receptor I; PTCL; NOS, peripheral T cell lymphoma; not otherwise specified; AITL, angioimmunoblastic T cell lymphoma; ALCL, anaplastic large cell lymphoma; CTCL, cutaneous T cell lymphoma; T-PLL, T-cell prolymphocytic leukemia; T-NHL, T cell non-Hodgkin lymphoma; FL, follicular lymphoma; MCL, mantle cell lymphoma; MZL, marginal zone lymphoma.

each subsequent line of therapy. ${ }^{18}$ Although CAR-T therapy is still early in development, early results promise to improve these outcomes considerably.

CAR-T cells targeting the CD19 antigen on B-NHL cells' surface are furthest in clinical development, with FDA-approved anti-CD19 CAR-T constructs for DLBCL and MCL and approvals for additional constructs and indications anticipated within the next 1-2 years.

Axicabtagene ciloleucel was the first anti-CD19 CAR-T approved for lymphoma in the United States. ${ }^{4}$ In the landmark Phase 2 ZUMA-1 study, 101 patients with DLBCL refractory to chemotherapy or relapsed after autologous stem cell transplant were treated with a single dose of axicabtagene ciloleucel, which elicited an $82 \%$ objective response rate and 54\% complete response rate. ${ }^{19}$ At a median follow-up of 15.4 months, $42 \%$ of patients had a continued response, with an unprecedented $40 \%$ still in complete response. ${ }^{19}$ The estimated 2-year progression-free survival of patients who were in $\mathrm{CR}$ at three months was $72 \%$. The latest long-term follow-up from the ZUMA-1 study (median follow-up 39.1 months) was presented at the ASH annual meeting in 2020 and reported durable responses with $47 \% 3$ years overall survival. ${ }^{20}$ Tisagenlecleucel is a second-generation anti-CD19 CAR-T construct that is commercially available for use in patients with relapsed/refractory DLBCL following at least two lines of prior therapy. In the phase 2 JULIET study, 93 relapsed/refractory DLBCL patients received tisagenlecleucel infusion. At a median follow-up of 14 months, the overall response rate was $52 \%$, with the majority of patients achieving a complete response, and the 12-month relapse-free survival was $79 \%$ in patients who achieved a complete response. ${ }^{21}$ In the TRANSCEND NHL 001 study, a third CD19-directed CAR-T therapy, lisocabtagene maraleucel, enrolled patients with a median of 
three previous lines of systemic treatment, and $67 \%$ had chemotherapy-refractory disease, $3 \%$ had secondary CNS involvement, $33 \%$ of patients had a previous autologous stem cell transplant, and 3\% had a previous allogenic stem cell transplant. ${ }^{22}$ TRANSCEND NHL 001 demonstrated $73 \%$ ORR and $53 \% \mathrm{CR}$ rate and has just received an approval for commercial use soon. ${ }^{5,22}$ Importantly, these unprecedented response rates have been confirmed in socalled "real world" or standard of care analyses, ${ }^{23-25}$ and older patients have also been shown to derive benefit from CAR-T administration with manageable side effects. ${ }^{26}$ Importantly, the safety analyses highlighted some differences in side effect profiles of these constructs. The JULIET study used a different grading system for CRS. However, the risk of grade $\geq 3$ cytokine release syndrome was notably lower with lisocabtagene maraleucel (2\% vs $13 \%$ and $22 \%$ with axicabtagene ciloleucel and tisagenlecleucel, respectively), and the risk of grade $\geq 3$ neurotoxicity was higher with axicabtagene ciloleucel $(28 \%$ vs $10-12 \%$ with the other two constructs). ${ }^{19,21,22}$

The current FDA indications for anti-CD19 CAR-T therapy in lymphoma require a failure of two lines of therapy. With more experience in the management of expected side effects of CAR-T therapy and the development of safer constructs, multiple studies are now investigating the incorporation of anti-CD19 CAR-T therapy earlier for chemo-refractory aggressive B-NHL. At a median follow-up of 3.5 months, all nine transplantineligible patients with DLBCL in the first relapse treated with lisocabtagene maraleucel in the PILOT study achieved an objective response with no CRS or neurologic events reported. ${ }^{27}$ Importantly, five of those patients were successfully treated in the outpatient setting. ${ }^{27}$ In the planned interim analysis of the ZUMA-12 trial, 15 patients with double-or triple-hit lymphoma who had FDG avid disease on an interim PET after 2 cycles of induction chemotherapy were treated with axicabtagene ciloleucel. Of those 15 patients with more than three months of follow-up after CAR-T infusion, $80 \%$ achieved a CR, with the majority achieving durable response. ${ }^{28,29}$ Axicabtagene ciloleucel is being evaluated in a Phase 3 study randomizing DLBCL patients who fail first-line therapy to standard salvage chemotherapy + autologous stem cell transplant versus axicabtagene ciloleucel (ZUMA-7, NCT03391466).

\section{CAR-T Cells for Mantle Cell Lymphoma}

In 2020, brexucabtagene autoleucel was approved for use in relapsed/refractory mantle cell lymphoma. ${ }^{6}$ The
ZUMA-2 study included patients relapsed after or refractory to at least two lines of therapy, including anti-CD20 therapy, anthracycline or bendamustine, and BTK inhibition. ${ }^{30}$ Of the 60 patients included in the efficacy analysis, $67 \%$ achieved a complete response, and $57 \%$ maintained their response at a median follow-up of 12.3 months. ${ }^{30}$ CRS was nearly universal $(91 \%)$ and occurred early with a median time to onset of 2 days, but grade $\geq 3$ CRS occurred in only $15 \%$, and there were no fatal CRS events. Neurotoxicity was also frequent $(31 \%$ grade $\geq 3$ neurologic events) but was fully reversible in the majority of patients (complete resolution in $86 \%$ of patients, the median time to resolution 12 days). ${ }^{30}$ The preliminary results of lisocabtagene maraleucel in relapsed/refractory mantle cell lymphoma suggest similar response rates and enhanced safety. Fifty-nine percent of relapsed/refractory MCL patients achieved CR after lisocabtagene maraleucel, including $57 \%$ of patients with blastoid variant MCL. CRS was seen in $50 \%$ of the cases, but only a single grade $\geq 3$ CRS event occurred, and less than $10 \%$ experienced grade $\geq 3$ neurologic events. ${ }^{31}$

\section{CAR-T Cells for Indolent Lymphoma}

CD19-directed CAR-T therapy has also demonstrated promising results in indolent B-NHL. The ORR for patients with indolent B-NHL (predominantly follicular lymphoma) treated with axicabtagene ciloleucel was $92 \%$, with a CR rate of $75 \%{ }^{32}$ Tisagenlecleucel has also demonstrated impressive preliminary overall and complete response rates ( $83 \%$ and $65 \%$, respectively) in relapsed/ refractory follicular lymphoma, with the median duration of response not reached. ${ }^{33}$ Multiple novel CD19 CAR-T constructs are still under investigation in B-NHL.

Due to concerns about the risk of neurotoxicity, in the registration studies for the currently approved anti-CD19 CAR-T therapies, patients with central nervous system involvement were excluded. However, "real world" experience in patients with DLBCL and secondary CNS involvement has shown no significant difference in the safety of axicabtagene ciloleucel or tisagenlecleucel. ${ }^{33-36}$ Future studies are explicitly targeting patients with CNS involvement. One such proposed study will investigate a novel CD19 CAR-T construct in patients with relapsed primary CNS lymphoma and is planned to incorporate both intravenous and direct intraventricular administration of CD19 CAR-T cells (NCT04443829). 


\section{CAR-T Cells for Hodgkin Lymphoma and T-Cell Lymphoma}

The superior efficacy of anti-CD19 CAR-T therapy and broad applicability in patients with aggressive B-NHL after multiple lines of therapy has led to trials evaluating alternative targets that may expand access to patients with Hodgkin lymphoma and $\mathrm{T}$ cell non-Hodgkin lymphoma. CD30 is a tumor necrosis factor receptor that is overexpressed in Hodgkin lymphoma and some T-NHL subtypes. ${ }^{37}$ Anti-CD30 therapy has proven successful in these lymphoma types, which has led to the exploration of anti-CD30 CAR-T therapy in patients with relapsed/refractory disease. In a study of anti-CD30 CAR-T therapy in patients with multiple relapsed Hodgkin lymphoma who had seen up to seven lines of prior therapy, including antiCD30 therapy with brentuximab vedotin, response rates were promising (ORR 72\%, CR 59\%) and durable. ${ }^{38}$ This construct has also been tested in a limited number of CD30 + anaplastic large cell lymphoma, a T-NHL subtype, with mixed results. ${ }^{39}$

\section{Multiple Myeloma CAR-T Cells in Clinical Trials}

After the approval of several new drugs in the last decade, the multiple myeloma management landscape has substantially changed. Treatment options for multiple myeloma have substantially improved over time, and therapeutic options include agents such as proteasome inhibitors (PIs), immunomodulatory drugs (IMiDs), monoclonal antibodies (MoAbs), antibody-drug conjugates, nuclear export inhibitors, and stem cell transplantation. However, overall survival for patients with IMiDs, PIs, and MoAbsrefractory disease remains around six months. ${ }^{40}$ Hence, new treatments with a novel mechanism of action are needed. Harnessing the immune system's ability to overcome refractoriness to conventional drugs can be achieved with monoclonal antibodies, antibody-drug conjugates, T-cell engagers, and chimeric T-cell based therapies.

Multiple myeloma CAR-T cells mostly targeted BCMA (also known as CD269 and TNFRSF17) in early clinical results. ${ }^{41}$ BCMA is a 20 kilodalton, type III membrane protein that is part of the tumor necrosis receptor superfamily. Initial clinical trials chose BCMA as the target because it is predominantly expressed in B-lineage cells and plays a critical role in B cell maturation and subsequent differentiation into plasma cells with a relatively higher expression on malignant plasma cells. ${ }^{41}$ Prior to delivering CAR-Ts, almost all clinical trials used the same conditioning chemotherapy of fludarabine $30 \mathrm{mg} / \mathrm{m}^{2}$ and cyclophosphamide $300 \mathrm{mg} / \mathrm{m}^{2}$ on days $-5,-4$, and -3 .

Currently, three major ongoing clinical trials pathways are exploring BCMA CAR-T. First, Idecabtagene Vicleucel (ide-cel) CAR-T cells for patients with relapsed/refractory multiple myeloma (RRMM). ${ }^{42}$ Ide-cel was tested in the KarMMa clinical trials; after lymphodepletion chemotherapy, it was given with a dose-escalation fashion then dose-expansion phase. The expansion phase enrolled patients who had received $\geq 3$ prior lines of therapy. The overall response rate for the expansion dose, $150-450 \times 10^{-6}$ CAR-T, was $76 \%$, including $39 \%$ patients with CR and 30 patients (out of 37 patients tested) achieving MRD negative status to the level $10^{-4}$ by next gene sequencing. Those results are unprecedented for patients with highly refractory multiple myeloma. Notably, the duration of response in that group of patients was around 11.3 months, and the median progression-free survival was around 12.1 months. Safety signal was significant for cytokine release syndrome (CRS) higher than or equal to grade 3 in about $7 \%$ of patients. The CRS incidence correlated with CAR-T dose. Out of 128 patients enrolled in the trial, 107 patients experienced CRS, while only seven patients had a CRS grade $\geq 3$. One patient had grade $5 \mathrm{CRS}^{43}$ Most patients required at least one dose of tocilizumab for CRS management. Twenty-seven percent of patients reported neurologic toxicity, which is mostly of grade $1 / 2$. However, one patient had grade 3 neurotoxicities and one patient had grade 4 neurotoxicities.

Building on those results, it was felt that enriching CAR-T cells with memory T-cells to increase the persistence of CAR-T cells will help with more durable responses. The bb21217 CAR-T cells are produced by culturing Ide-cel with a PI3K inhibitor. ${ }^{44}$ Clinically, bb21217 is undergoing a Phase 1 multicenter study for MM patients who received $\geq 3$ prior regimens, including PI and IMiD agents. Investigators published initial results on 44 patients. The CR rate was $18 \%$. CRS developed in $67 \%$ of patients, including one patient with grade $5 \mathrm{CRS}$. More importantly, higher expression of CD127, a long-lasting memory T-cell marker, was positively correlated with duration of response (DOR), while multiple markers were associated with differentiated T-cells and exhaustion (eg EOMES,+ TBET + ) correlated negatively with DOR. ${ }^{45}$

Secondly, Orvacabtagene-Autoleucel (orva-cel), also previously known as JCARH125, is equipped with 
a fully human binder. ${ }^{46}$ Orva-cell was evaluated in the EVOLVE phase 1 study and showed promising results with CAR-T dosing between 50 and $150 \times 10^{6}$ cells without dose-limiting toxicities. ${ }^{47}$ Recently, another 51 patients were added to the EVOLVE dose escalation with CAR-T dose between $300-600 \times 10^{6}$ cells after lymphodepleting chemotherapy. Orva-cel yielded a 91\% ORR with $39 \%$ CR in a highly refractory population. However, it is too early to report on the final overall survival or median PFS. ${ }^{46}$ Based on those results, another ongoing trial, NCT04394650, is testing the next generation manufacturing platform designed to deliver a CAR T-cell product with less-differentiated composition and reduce turnaround time $\left(\mathrm{Nex}-\mathrm{T}^{\mathrm{TM}}\right)$. Nex-T CAR-T will likely replace orvacel.

Third, Ciltacabtagene Autoleucel (Cilta-Cel), ${ }^{48}$ also known as LCAR-B38M or JNJ-4528, is genetically engineered to contain a 4-1BB costimulatory domain and two binding sites that attach to BCMA to confer avidity. The overall response rate was $94.8 \%$ (95\% CI 88.4-98.3), with a stringent CR rate of $55.7 \%$ (95\% CI 45.2-65.8), VGPR of $32.0 \%$ (95\% CI 22.9-42.2), and partial response rate of $7.2 \%$ (95\% CI 3.0-14.3). Also, out of 52 patients with evaluable minimal residual disease (MRD), $94.2 \%$ were MRD negative $10^{-5}$ by next gene sequencing. The 6-month PFS and OS rates were $87.4 \%$ and $93.8 \%$, respectively. Unfortunately, eight patients died during the trial due to toxicities. Table (3) summerizes pivotal CAR-T trials.

\section{CAR-T Related Toxicities Cytokine Release Syndrome (CRS)}

CRS is a systemic inflammatory response observed after adoptive T-cell therapy. This condition results from upregulation of CD25 and CD69, secretion of cytokines IL-6, IL-10 and IFN $\gamma$, the proliferation of immune cells, and production of granzyme and perforin. ${ }^{49}$ This toxicity is non-antigen specific, and it is related to high immune activation and, in some patients, CRS-related clinical and laboratory findings are like macrophage activation syndrome/hemophagocytic lymphohistiocytosis (MAS/HLH).

Clinically, CRS presents with cardiac (tachycardia and arrhythmias), gastrointestinal (nausea and vomiting), laboratory (coagulation, renal and hepatic), neurological, respiratory, skin, vascular (hypotension), and constitutional (fever, rigors, headaches, malaise, fatigue arthralgia) symptoms. However, after ruling out infection, fever, hypotension, and hypoxia are the mainstay of CRS clinical manifestations. ${ }^{50}$
Initial reports speculated that CRS is essential for clinical response against cancer; however, it is clear now that tumor burden is also related to the increased incidence of CRS, ${ }^{51}$ and the absence of CRS does not preclude tumor response.

CRS is graded by different methods with minor difference. ${ }^{50,52,53}$ In general, CRS severity depends on hypotension and hypoxia. Earlier, Lee et $\mathrm{al}^{53}$ published criteria for grading CRS, which was later modified to the ASTCT criteria. $^{50}$ However, CRS-induced end-organ damage remains a part of the CTCAE (currently v. 5.0) grading system. ${ }^{54}$

While grade 1 CRS is defined as the presence of constitutional symptoms with or without fever, mild hypotension and mild hypoxia are the mainstays of grade 2 CRS. However, hypotension that requires vasopressors or hypoxia that requires a low-flow nasal cannula $(6 \mathrm{~L} / \mathrm{min}$ ute) is considered grade 3 CRS. The use of multiple vasopressors (excluding vasopressin) or hypoxia requiring positive pressure defines grade 4 CRS. ${ }^{54}$

Management of CRS syndrome is summarized in Figure 2. The management of CRS grade $\geq 2$ requires tocilizumab. At least two doses of tocilizumab must be available before infusion of CAR-T cells. In severe or refractory cases, siltuximab, anakinra, and cyclophosphamide might be helpful. Figure 2 .

\section{Neurotoxicity: Immune Effector Cell-Associated Toxicity (ICANS)}

The earliest manifestations of ICANS are tremor, dysgraphia, mild difficulty with expressive speech (especially in naming objects), impaired attention, apraxia, and mild lethargy. Seizures are possible, hence the use of levetiracetam prophylaxis in most CAR-T protocols. ${ }^{55}$ In general, the diagnosis is made by clinical symptoms. Except with seizures, electroencephalography (EEG) or brain imaging findings are non-specific in ICANs. ${ }^{56}$ However, MRI brain might be helpful to role out while the underlying mechanisms. The increased blood-brain barrier permeability does not shield the CSF from high serum cytokine concentrations; also, the presence of CAR-T cells in CSF might play a role in producing local cytokines. ${ }^{57}$ Nonetheless, the exact mechanism behind neurotoxicity is not fully elucidated. While severe neurotoxicity is more common with severe CRS, ICANS could also happen without CRS. Early severe CRS (within 36 hours) with elevated IL-6 and monocyte chemoattractant protein-1 (MCP) might indicate a higher risk for developing ICANS. ${ }^{56}$ 


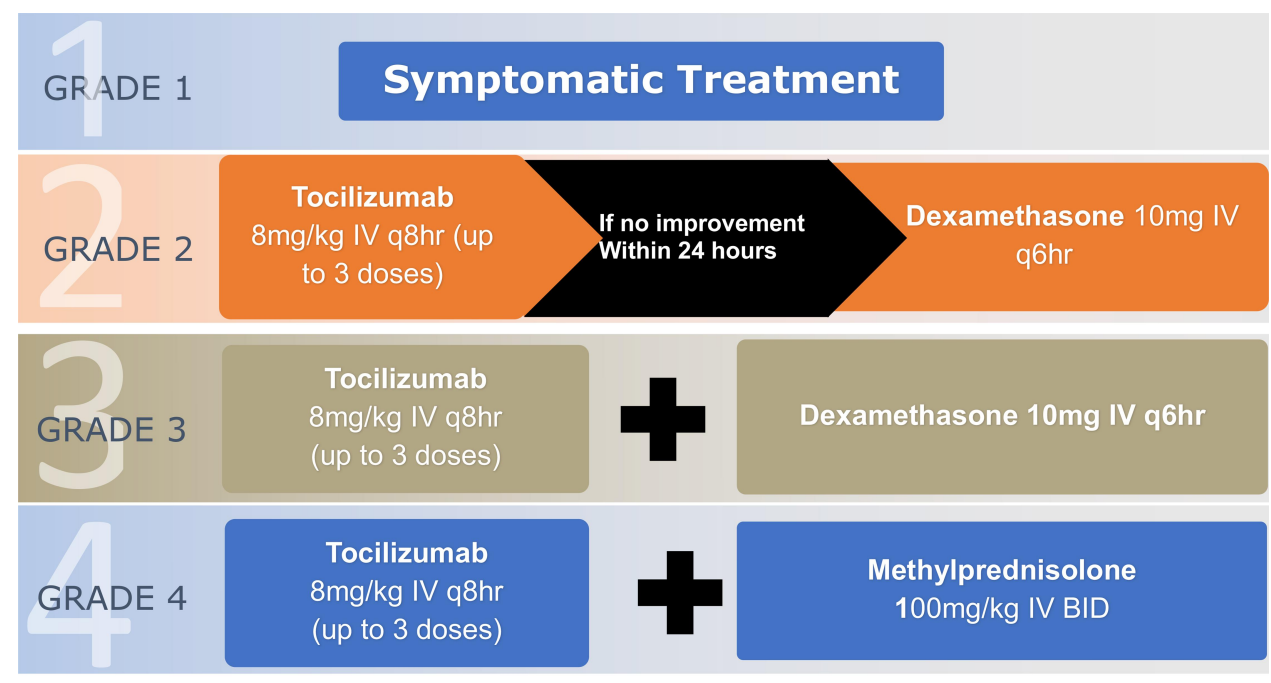

\begin{tabular}{|c|c|c|}
\hline & \multicolumn{2}{|c|}{ Management of Neurotoxicity } \\
\hline & Concurrent CRS & No Concurrent CRS \\
\hline Grade 1 & Symptomatic treatment & Symptomatic treatment \\
\hline Grade 2 & $\begin{array}{l}\text { Tocilizumab } 8 \mathrm{mg} / \mathrm{kg} \mathrm{IV} \text {; } \\
\text { repeat q8hr (up to } 3 \text { doses) } \\
\text { If no improvement within } 24 \mathrm{hrs} \\
\text { administer } \\
\text { Dexamethasone } 10 \mathrm{mg} I \mathrm{~V} \text { q6hr }\end{array}$ & $\begin{array}{l}\text { Dexamethasone } \\
10 \mathrm{mg} \text { IV q6hr }\end{array}$ \\
\hline Grade 3 & $\begin{array}{l}\text { Tocilizumab } 8 \mathrm{mg} / \mathrm{kg} \mathrm{IV} \text {; } \\
\text { repeat q8hr (up to } 3 \text { doses) } \\
\text { + Dexamethasone } 10 \mathrm{mg} \text { IV q6hr }\end{array}$ & $\begin{array}{l}\text { Dexamethasone } \\
10 \mathrm{mg} \text { IV q6hr }\end{array}$ \\
\hline Grade 4 & $\begin{array}{l}\text { Tocilizumab } 8 \mathrm{mg} / \mathrm{kg} \text { IV; } \\
\text { repeat q8hr (up to } 3 \text { doses) } \\
+ \text { Methylprednisolone } 1000 \mathrm{mg} / \mathrm{kg} \text { IV } \\
\text { per day with first dose of tocilizumab }\end{array}$ & $\begin{array}{l}\text { Methylprednisolone } \\
1000 \mathrm{mg} / \mathrm{kg} \text { IV } \\
\text { per day for } 3 \text { days }\end{array}$ \\
\hline
\end{tabular}

Figure 2 Management to CRS/neurotoxicity.

The CAR-T-cell-therapy-associated toxicity 10-point neurological assessment (CARTOX-10) is one of the most commonly used scores because it is easy to use clinically. ${ }^{55}$ In the CARTOX-10, one point is assigned for each of the following tasks that are performed correctly: orientation to year, month, city, hospital, and President/Prime Minister of the country of residence (total of 5 points); name three objects (maximum of 3 points); write a standard sentence (1 point). Normal cognitive function is defined by an overall score of 10 . A score between 7-9 defines Grade-one (mild impairment); the grade-two score is 3-6; while a score of $0-2$, stage 1-2 papilloedema, CSF opening pressure $<20 \mathrm{mmHg}$ or partial/non-convulsive seizure on EEG that is responding to benzodiazepine defines grade-three (severe impairment). Grade four is obtundation, stage three to five papilloedema, CSF opening pressure $\geq 20 \mathrm{mmHg}$, cerebral edema, or generalized seizure/unresponsive nonconvulsive status epilepticus. Figure 2 includes a summary of ICANS treatment.

\section{Challenges and Future Directions Challenges with Clinical Efficacy}

Despite the success rates, some patients relapse after CAR-T therapy. Also, in myeloma, anti-BCMA CARTs have limited clinical efficacy with a median progression-free survival $<12$ months. In addition, in lymphoma, not all patients achieve a durable response with anti-CD19 CAR-Ts. This limitation is due to multiple factors: 
Table 2 Directed CAR-T Studies in Lymphoma

\begin{tabular}{|c|c|c|}
\hline \multicolumn{3}{|c|}{ Challenge: Limited Efficacy of CDI9 CAR-Ts in B-NHL } \\
\hline Strategies Under Investigation & Selected Clinical Trials & Refs \\
\hline $\begin{array}{l}\text { Tandem/Multiplexed CAR-T therapy to } \\
\text { reduce CDI9 escape }\end{array}$ & $\begin{array}{l}\text { NCT04260932, NCT04697290, NCT0388I76I, NCT047239I4, NCT03870945, NCT0327I5I5, } \\
\text { NCT04486872, NCT042I50I6, NCT04007029, NCT04553393 (CDI9/CD20 CAR-T) } \\
\text { NCT047I527I, NCT04539444, NCT03593I09, NCT04648475, NCT04649983, NCT04204I6I, } \\
\text { NCT032878I7, NCT044I2I74, NCT04626908, NCT04029038 (CDI9/CD22 CAR-T) } \\
\text { NCT04603872, NCT04I62353 (CDI9/BCMA CAR-T) } \\
\text { NCT04429438 (multiple targets) }\end{array}$ & \\
\hline $\begin{array}{l}\text { Adjunctive therapy to improve efficacy of } \\
\text { CDI9 }\end{array}$ & $\begin{array}{l}\text { NCT0438I74I, NCT04I63302, NCT04539444, NCT02706405 (PDI inhibition) } \\
\text { NCT044840I2, NCT04257578 (Acalabrutinib) } \\
\text { NCT0423406I (ibrutinib) } \\
\text { NCT04697940, NCT04553393 (Decitabine) } \\
\text { NCT033I06I9 (multiple combinations) }\end{array}$ & $\begin{array}{l}{[50]} \\
{[51]}\end{array}$ \\
\hline Modified CDI9 CAR constructs & $\begin{array}{l}\text { NCT03929I07, NCT0438I74I (IL7 × CCLI9 expression) } \\
\text { NCT042 I3469 (PDI knockout) } \\
\text { NCT0379089I, NCT03497533, NCT03720496, NCT039I0842 (PDLI inhibition and Tactivation domains) } \\
\text { NCT04037566 (HPKI edited) } \\
\text { NCT04450069 (adaptable CAR-T construct) }\end{array}$ & [52] \\
\hline Consolidative allogeneic HSCT & NCT03366350, NCT03III0640 & \\
\hline \multicolumn{3}{|c|}{ Challenge: Undefined Treatments for B-NHL Post-CDI9 CAR-T Relapse } \\
\hline Strategies Under Investigation & Selected Clinical Trials & Refs \\
\hline Retreatment with CDI9 CAR-T & NCT04419909 & \\
\hline Treatment with alternatively targeted CAR-Ts & NCT04036019, NCT043I6624 (CD20 CAR-T) & \\
\hline $\begin{array}{l}\text { Other immunotherapies/ } \\
\text { immunomodulatory therapies }\end{array}$ & $\begin{array}{l}\text { NCT04703686, NCT0229095I (CD20 x CD3 bispecific Ab) } \\
\text { NCT02650999 (pembrolizumab) } \\
\text { NCT02926833 (atezolizumab) } \\
\text { NCT04205409 (nivolumab) } \\
\text { NCT04I36756 (NKTR-255) } \\
\text { NCT03648372 (TAK-98I) } \\
\text { NCT04074330 (TAK-98I + rituximab) }\end{array}$ & \\
\hline $\begin{array}{l}\text { Radiation therapy to residual sites to re- } \\
\text { prime response }\end{array}$ & NCT0460I83I, NCT04473937 & \\
\hline \multicolumn{3}{|c|}{ Challenge: Limited Access to CAR-T Therapy } \\
\hline Strategies Under Investigation & Selected Clinical Trials & Refs \\
\hline $\begin{array}{l}\text { Outpatient administration of CAR-T } \\
\text { Allogeneic CAR-T therapy }\end{array}$ & $\begin{array}{l}\text { NCT03744676, NCT0I85363I, NCT03233854 } \\
\text { NCT03939026, NCT044I6984, NCT04637763, NCT03I66878, NCT04264039, NCT03666000, } \\
\text { NCT04026I00, NCT03229876, NCT04035434, NCT04629729 (CDI9) } \\
\text { NCT03398967 (CDI9 + CD20/CD22) } \\
\text { NCT04030I95 (CD20) } \\
\text { NCT04264078, NCT04620655 (CD7) } \\
\text { NCT04502446 (CD70) } \\
\text { NCT04288726 (CD30) } \\
\text { NCT0388I774 (cord blood derived CAR-T) } \\
\text { NCT0I430390 (EBV-CTL CAR-T) }\end{array}$ & \\
\hline Shorten manufacturing time & $\begin{array}{l}\text { NCT04638270 (CDI9) } \\
\text { NCT04303247 (CDI9 + CD22) }\end{array}$ & \\
\hline
\end{tabular}

(Continued) 
Table 2 (Continued).

\begin{tabular}{|c|c|c|}
\hline New indications & NCT04443829, NCT04532203, NCT4608487 (PCNSL) & \\
\hline Earlier employment of CAR-T therapy & NCT0453I046, NCT03570892, NCT03483I03 & \\
\hline \multicolumn{3}{|l|}{ Alternative targets in: } \\
\hline Hodgkin lymphoma & $\begin{array}{l}\text { NCT03383965, NCT02917083, NCT04268706, NCT04653649, NCT04526834, NCT03049449, } \\
\text { NCT03602157, NCT04008394, NCT02663297, NCT04083495, NCT02690545 (CD30) }\end{array}$ & \\
\hline Peripheral T cell lymphoma & $\begin{array}{l}\text { NCT04004637, NCT04033302, NCT04599556, NCT036900II, NCT04480788 (CD7) } \\
\text { NCT04594I35, NCT0308I9I0 (CD5) } \\
\text { NCT03590574 (TRBCI) } \\
\text { NCT042193I9, NCT04I62340, }\end{array}$ & \\
\hline Cutaneous $T$ cell lymphoma & NCT047I2864, NCT03829540 (CD4) & \\
\hline B-cell non-Hodgkin lymphoma & $\begin{array}{l}\text { NCT04I69932, NCT03664635, NCT04I769I3, NCT03277729 (CD20) } \\
\text { NCT04I63575, NCT0457II38, NCT04007978, NCT03262298, NCT023I56I2 (CD22) } \\
\text { NCT0460924I (CD79b) } \\
\text { NCT04662294 (CD70) } \\
\text { NCT02954445 (BCMA) } \\
\text { NCT04223765 (kappa light chain) } \\
\text { NCT02706392 (RORI) } \\
\text { NCT04I } 36275 \text { (CD37) } \\
\text { NCT04427449 (CD44v6) }\end{array}$ & \\
\hline \multicolumn{3}{|c|}{ Challenge: Safety Concerns with CAR-T Therapy } \\
\hline Strategies Under Investigation & Selected Clinical Trials & Refs \\
\hline Targeted studies in vulnerable populations & $\begin{array}{l}\text { NCT0466I } 020 \text { (elderly) } \\
\text { NCT04088864, NCT046I0I25, NCT0337307I, NCT03448393, NCT0324I940 (pediatrics) }\end{array}$ & \\
\hline $\begin{array}{l}\text { Adjunctive therapies to prevent CRS/ } \\
\text { neurotoxicity }\end{array}$ & $\begin{array}{l}\text { NCT04359784, NCT04432506, NCT04I48430, NCT04I509I3, NCT04205838 (anakinra) } \\
\text { NCT04603872 (dasatinib) } \\
\text { NCT03954I } 06 \text { (defibrotide) } \\
\text { NCT045I4029 (IT dexamethasone + simvastatin) } \\
\text { NCT043I } 4843 \text { (lenzilumab) }\end{array}$ & {$[106]$} \\
\hline Inducible "safety switch" & NCT03696784 (Caspase 9) & \\
\hline
\end{tabular}

1. Intrinsic factors due to CAR-T exhaustion or senescence leading to target-positive relapses. A potential strategy to overcome this would be using naïve and stem/central memory CAR-T because it has a better proliferation ability to overcome this exhaustion. ${ }^{58}$

2. Tumor-related factors relating to target loss; for example, biallelic loss of BCMA might play a role against reapplying the same CAR-T treatment upon progression. ${ }^{59}$ One future option here is to include more than one target in CAR-T design. Another option is to target the ligand of the receptor; for example, in myeloma, a proliferation-inducing ligand (APRIL) is a ligand of BCMA and
Transmembrane activator and CAML interactor (TACI); therefore, by targeting APRIL, we could exploit the benefits of BCMA and avoid tumor escaping mechanism. ${ }^{60}$

Clinical trials are underway, incorporating CAR-T with multiple targets to improve efficacy and reduce antigenic escape. Both sequential and combinatorial CAR-T therapy are being investigated. One example in lymphoma is the dose-finding study of MB-CART2019.1, the tandem CD19 and CD20 targeted CAR-T product was well tolerated and had promising response rates in lymphoma patients. ${ }^{61,62} \mathrm{CD} 22, \mathrm{CD} 30, \mathrm{CD} 38$, 
Table 3 BCMA Directed CAR-T Studies in Myeloma

\begin{tabular}{|c|c|c|c|c|c|}
\hline & $\begin{array}{l}\text { Idecabtagene } \\
\text { Vicleucel (Ide-Cel) } \\
\text { /bb2 I } 2 \text { I }\end{array}$ & bb2 1217 & $\begin{array}{l}\text { Orvacabtagene- } \\
\text { Autoleucel } \\
\text { (Orva-Cel) }\end{array}$ & $\begin{array}{l}\text { Ciltacabtagene } \\
\text { Autoleucel (Cilta-Cel) } \\
\text { /LCAR-B38M }\end{array}$ & $\begin{array}{l}\text { P- BCMA- } \\
101\end{array}$ \\
\hline Sponsor & BMS & BMS & BMS & Jansen/China & $\begin{array}{l}\text { Poseida } \\
\text { Therapeutics }\end{array}$ \\
\hline Study & $\begin{array}{l}\text { KARMMA Study } \\
\text { CRB-40I }^{13,42,43}\end{array}$ & CRB- $402^{44}$ & $\begin{array}{l}\text { EVOLVE Ph I/2 } \\
\text { Trial }^{46}\end{array}$ & $\begin{array}{l}\text { CARTITUDE- }{ }^{48} / \\
\text { LEGEND }\end{array}$ & PRIME $^{107}$ \\
\hline Design & Lentiviral vector 4-IBB & $\begin{array}{l}\text { Ide-cel cultured with } \\
\text { PI3Ki to enrich memory } \\
\text { like T cells }\end{array}$ & $\begin{array}{l}\text { Fully human } \\
\text { (CD28/4IBB). } \\
\text { I:I CD4:CD8 ratio }\end{array}$ & $\begin{array}{l}\text { BCMA-targeting with two } \\
\text { single chain binding sites }\end{array}$ & $\begin{array}{l}\text { PiggyBac }^{\circledR} \\
\text { transposon- } \\
\text { based system }\end{array}$ \\
\hline Population (n) & 128 patients & $\begin{array}{l}24 \text { escalation and } 22 \text { in } \\
\text { expansion }\end{array}$ & $\begin{array}{l}51 \text { pts dose } \\
\text { escalation }\end{array}$ & $\begin{array}{l}97 \text { pts ( } 29 \text { in Phasel, } 68 \text { in } \\
\text { Phase2) }\end{array}$ & 43 pts \\
\hline $\begin{array}{l}\text { Median Number of } \\
\text { Prior lines }\end{array}$ & 6 lines & 6 lines & 6 lines & & 7 \\
\hline CAR-T dose (cell/kg) & $150-450 \times 10^{6}$ & $150-450 \times 10^{6}$ & $300-600 \times 10^{6}$ & Target dose of $0.75 \times 10^{6}$ & $0.75-15 \times 10^{6}$ \\
\hline Refractory to IMiD and $\mathrm{PI}$ & $98 \%$ & - & - & - & $100 \%$ \\
\hline $\begin{array}{l}\text { Refractory to IMiD, PI, } \\
\text { and CD38 MoAb }\end{array}$ & $84 \%$ & $57 \%$ & $92 \%$ exposed & $\begin{array}{l}87.6 \% \\
41.2 \% \text { penta-refractory }\end{array}$ & $93 \%$ \\
\hline Previous ASCT & $94 \%$ & - & - & - & $58 \%$ \\
\hline ORR & $73 \%$ & $55 \%$ & $91 \%$ & $94.8 \%$ & $57 \%$ \\
\hline$C R \geq$ & $33 \%$ & $18 \%$ & $39 \%$ & $55.7 \%$ & \\
\hline PFS/DFS/DOR & 10.7 months & 11.9 months & - & NR & - \\
\hline OS & 19.4 months & & - & NR & - \\
\hline Median time to CRS & I day & 3 days & & 7 days & - \\
\hline Grade 3/4 CRS & $6 \%$ & 2 pts (I death) & l pt & $4.1 \%$ & I pt \\
\hline Neurotoxicity $\geq$ grade 3 & $3 \%$ & 3 pts & 2 pts & $10.3 \%$ & $\mathrm{lpt}$ \\
\hline Reference & $\begin{array}{l}\text { NEJM/ASH2020 } \\
\text { NCT02658929 }\end{array}$ & $\begin{array}{l}\text { ASH2020 } \\
\text { NCT03274219 }\end{array}$ & $\begin{array}{l}\text { ASCO2020 } \\
\text { NCT034300II }\end{array}$ & $\begin{array}{l}\text { ASH2020 } \\
\text { NCT03548207 }\end{array}$ & $\begin{array}{l}\text { ASH2020 } \\
\text { NCT03288493 }\end{array}$ \\
\hline Next generation & $\mathrm{Bb} 21217$ & - & NEX-T & - & Nano-plasmid \\
\hline
\end{tabular}

and CD70 directed CARs are additional targets under investigation in conjunction with CD19 CAR-Ts in B-NHL (Tables 1 and 2) ${ }^{63,64}$ It remains to be seen if these multi-targeted CAR-T constructs will produce more remissions.

3. Tumor-microenvironment related factors. Some patients relapse with target + cells and CAR-T circulating. This type of relapse suggests that CAR-T cell persistence and antigen presence are not sufficient to exert immunity. Perhaps immune suppression in the tumor microenvironment may have a role here.

Finally, the best timing of CAR-T administration in earlier lines of treatment remains questionable.

\section{Challenges with Target Selection}

Targeting $\mathrm{T}$ cell antigens for peripheral and cutaneous $\mathrm{T}$ cell lymphoma has proven challenging. $\mathrm{T}$ cell antigens 
are frequently downregulated or lost during $\mathrm{T}$ cell lymphomagenesis, ${ }^{65}$ limiting CAR-T's applicability in $\mathrm{T}$ cell non-Hodgkin lymphoma. Furthermore, expression of the target antigen on the CAR-T cell surface results in fratricide, with blunted expansion and CAR-T cells' reduced viability. Finally, targeting markers expressed by normal $\mathrm{T}$ cells results in profound immunosuppression and risk of infection, in contrast to B-cell aplasia seen with CD19 CAR-T, resulting in hypogammaglobulinemia. Nevertheless, $\mathrm{T}$ cell antigen targets such as CD4, CD5, CD7, CD37, and TRBC1 (Table 1) are in clinical development for lymphoma patients. Other promising targets such as NKG2D, APRIL, GPRC5D, and FcRH5 are following. (Table 1) Additional modification of the CAR-T cells to down-regulate the target antigen expression has been employed to counteract fratricide. ${ }^{66}$ Incorporation of a "kill switch" may reduce the risk of T-cell aplasia.

\section{The Future of CAR-T Manufacturing}

Currently approved anti-CD19 CAR-T therapies are autologous products, which may require up to four weeks for manufacturing. For patients whose disease progresses rapidly, this constraint may deprive a portion of patients of this potentially life-saving therapy. Induced pluripotent stem cells were transduced with target-specific or BCMA chimeric antigen receptors to generate CAR-Ts that demonstrated effective target-specific cell killing in preclinical studies. ${ }^{67}$ This technology is being developed to generate a renewable source of allogenic CAR-T products that may significantly reduce the time from patient identification to CAR-T infusion. ${ }^{10}$ Off-the-shelf, allogenic CAR-Ts from various sources and targeting various tumor-specific antigens are currently in clinical development (Table 2). In addition to the typical side effects of autologous CAR-Ts, allogenic CAR-Ts have additional potential but not insurmountable complications, including graft versus host disease and graft rejection. Similarly, derived allogenic CAR-NK (natural killer) cells are also under investigation.

\section{Conclusion}

Mounting evidence indicates that immune therapy will be the next revolution in hematological malignancies care. CAR-Ts' technology is a platform with vast opportunities to develop a plethora of different manufacturing techniques and structures. Many questions remain unanswered relating to the target selection and best timing in treatment lines to employ CAR-T therapy. However, this treatment is a launchpad for unlimited possibilities in the future.

\section{Disclosure}

SA reports honorarium from Takeda, Amgen, Karyopharm, BMS, Sanofi, Cellactar, Janssen, and Celgene; speaker bureau for Celgene, Janssen, and Sanofi. TKM reports honorarium Seattle Genetics. The authors report no other conflicts of interest in this work.

\section{References}

1. Siegel RL, Miller KD, Jemal A. Cancer statistics, 2020. $C A$ Cancer J Clin. 2020;70(1):7-30. doi:10.3322/caac.21590

2. Joseph NS, Kaufman JL, Dhodapkar MV, et al. Long-term follow-up results of lenalidomide, bortezomib, and dexamethasone induction therapy and risk-adapted maintenance approach in newly diagnosed multiple myeloma. J Clin Oncol. 2020;JCO1902515.

3. Gonzalez H, Hagerling C, Werb Z. Roles of the immune system in cancer: from tumor initiation to metastatic progression. Genes Dev. 2018;32(19-20):1267-1284. doi:10.1101/gad.314617.118

4. Bouchkouj N, Kasamon YL, de Claro RA, et al. FDA approval summary: axicabtagene ciloleucel for relapsed or refractory large B-cell lymphoma. Clin Cancer Res. 2019;25(6):1702-1708. doi:10.1158/1078-0432.CCR-18-2743

5. Research $\mathrm{C}$ for DE and FDA approves lisocabtagene maraleucel for relapsed or refractory large B-cell lymphoma. FDA; 2021

6. US Food \& Drug Administration. FDA approves first cell-based gene therapy for adult patients with relapsed or refractory MCL. Available from: https://www.fda.gov/news-events/press-announce ments/fda-approves-first-cell-based-gene-therapy-adult-patientsrelapsed-or-refractory-mcl. Accessed March 18, 2021.

7. Hudecek M, Izsvák Z, Johnen S, et al. Going non-viral: the Sleeping Beauty transposon system breaks on through to the clinical side. Crit Rev Biochem Mol Biol. 2017;52(4):355-380. doi:10.1080/10409238.2017.1304354

8. Woodard LE, Wilson MH. piggyBac-ing models and new therapeutic strategies. Trends Biotechnol. 2015;33(9):525-533. doi:10. 1016/j.tibtech.2015.06.009

9. Mailankody S, Matous JV, Liedtke M, et al. Universal: an Allogeneic First-in-Human Study of the Anti-Bcma ALLO-715 and the Anti-CD52 ALLO-647 in relapsed/refractory multiple myeloma. Blood. 2020;136 (Supplement 1):24-25. doi:10.1182/blood-2020-140641

10. Park JH, Jain N, Chen A, et al. A Phase I Study of FT819, a First-of-Kind, off-the-Shelf, iPSC-derived TCR-less CD19 CAR $\mathrm{T}$ cell therapy for the treatment of relapsed/refractory B-cell malignancies. Blood. 2020;136(Supplement 1):15-16. doi:10.11 82/blood-2020-142423

11. Maude SL, Frey N, Shaw PA, et al. Chimeric antigen receptor $\mathrm{T}$ cells for sustained remissions in leukemia. $N$ Engl $\mathrm{J} \mathrm{Med.}$ 2014;371(16):1507-1517. doi:10.1056/NEJMoa1407222

12. Chimeric antigen receptor-modified $\mathrm{T}$ cells in chronic lymphoid leukemia; Chimeric antigen receptor-modified $\mathrm{T}$ cells for acute lymphoid leukemia; Chimeric antigen receptor $\mathrm{T}$ cells for sustained remissions in leukemia. N Engl J Med. 2016;374(10):998. doi:10.1056/NEJMx160005

13. Munshi NC, Anderson LD, Shah N, et al. Idecabtagene vicleucel in relapsed and refractory multiple myeloma. $N$ Engl $\mathrm{J}$ Med. 2021;384(8):705-716. doi:10.1056/NEJMoa2024850

14. Wang K, Wei G, Liu D. CD19: a biomarker for B cell development, lymphoma diagnosis and therapy. Exp Hematol Oncol. 2012;1(1):36. doi:10.1186/2162-3619-1-36

15. Sanchez E, Li M, Kitto A, et al. Serum B-cell maturation antigen is elevated in multiple myeloma and correlates with disease status and survival. Br J Haematol. 2012;158(6):727-738. doi:10.1111/ j.1365-2141.2012.09241.x 
16. Crump M, Neelapu SS, Farooq U, et al. Outcomes in refractory diffuse large B-cell lymphoma: results from the international SCHOLAR-1 Study. Blood. 2017;130(16):1800-1808. doi:10.11 82/blood-2017-03-769620

17. Martin P, Maddocks K, Leonard JP, et al. Postibrutinib outcomes in patients with mantle cell lymphoma. Blood. 2016;127 (12):1559-1563. doi:10.1182/blood-2015-10-673145

18. Rivas-Delgado A, Magnano L, Moreno-Velázquez $\mathrm{M}$, et al. Response duration and survival shorten after each relapse in patients with follicular lymphoma treated in the rituximab era. Br J Haematol. 2019;184(5):753-759. doi:10.1111/bjh.15708

19. Neelapu SS, Locke FL, Bartlett NL, et al. Axicabtagene ciloleucel CAR T-cell therapy in refractory large B-cell lymphoma. $N$ Engl J Med. 2017;377(26):2531-2544. doi:10.1056/NEJMoa1707447

20. Jacobson C, Locke FL, Ghobadi A, et al. Long-term survival and gradual recovery of $\mathrm{B}$ cells in patients with refractory large $\mathrm{B}$ cell lymphoma treated with axicabtagene ciloleucel (Axi-Cel). Blood. 2020;136(Supplement 1):40-42.

21. Schuster SJ, Bishop MR, Tam CS, et al. Tisagenlecleucel in adult relapsed or refractory diffuse large B-cell lymphoma. $N$ Engl $J$ Med. 2019;380(1):45-56. doi:10.1056/NEJMoa1804980

22. Abramson JS, Palomba ML, Gordon LI, et al. Lisocabtagene maraleucel for patients with relapsed or refractory large B-cell lymphomas (TRANSCEND NHL 001): a multicentre seamless design study. Lancet. 2020;396(10254):839-852. doi:10.1016/ S0140-6736(20)31366-0

23. Nastoupil LJ, Jain MD, Feng L, et al. Standard-of-care axicabtagene ciloleucel for relapsed or refractory large B-cell lymphoma: results from the US Lymphoma CAR T Consortium. J Clin Oncol. 2020;38(27):3119-3128. doi:10.1200/JCO.19.02104

24. Jacobson CA, Hunter BD, Redd R, et al. Axicabtagene ciloleucel in the non-trial setting: outcomes and correlates of response, resistance, and toxicity. J Clin Oncol. 2020;38(27):3095-3106. doi:10.1200/JCO.19.02103

25. Iacoboni G, Iraola-Truchuelo J, Martinez-Cibrian N, et al. Realworld evidence of tisagenlecleucel for the treatment of relapsed or refractory large B-cell lymphoma. Blood. 2020;136(Supplement 1):19-21. doi:10.1182/blood-2020-136201

26. Neelapu SS, Jacobson CA, Oluwole OO, et al. Outcomes of older patients in ZUMA-1, a pivotal study of axicabtagene ciloleucel in refractory large B-cell lymphoma. Blood. 2020;135(23):21 06-2109. doi:10.1182/blood.2019004162

27. Sehgal AR, Godwin J, Pribble J, et al. Lisocabtagene maraleucel (liso-cel) for treatment of second-line transplant noneligible (TNE) Relapsed/Refractory (R/R) Aggressive Non-Hodgkin Lymphoma (NHL): initial Results from the PILOT Study. Blood. 2019;134 (Supplement_1):2882. doi:10.1182/blood-2019-127658

28. Neelapu SS, Dickinson M, Ulrickson ML, et al. Interim analysis of ZUMA-12: a Phase 2 Study of Axicabtagene Ciloleucel (Axi-Cel) as First-Line Therapy in Patients (Pts) With High-Risk Large B Cell Lymphoma (LBCL). Blood. 2020;136 (Supplement 1):49. doi:10.1182/blood-2020-134449

29. Hsi ED, Steinle R, Balasa B, et al. CS1, a potential new therapeutic antibody target for the treatment of multiple myeloma. Clin Cancer Res. 2008;14(9):2775-2784. doi:10.1158/1078-0432.CCR-07-4246

30. Wang M, Munoz J, Goy A, et al. KTE-X19 CAR T-cell therapy in relapsed or refractory mantle-cell lymphoma. $N$ Engl J Med. 2020;382(14):1331-1342. doi:10.1056/NEJMoa1914347

31. Palomba ML, Gordon LI, Siddiqi T, et al. Safety and preliminary efficacy in patients with relapsed/refractory mantle cell lymphoma receiving lisocabtagene maraleucel in transcend NHL 001. Blood. 2020;136(Supplement 1):10-11. doi:10.1182/blood-2020-136158
32. Jacobson C, Chavez JC, Sehgal AR, et al. Primary Analysis of Zuma-5: a Phase 2 Study of Axicabtagene Ciloleucel (Axi-Cel) in Patients with Relapsed/Refractory (R/R) Indolent Non-Hodgkin Lymphoma (iNHL). Blood. 2020;136 (Supplement 1):40-41.

33. Fowler NH, Dickinson M, Dreyling M, et al. Efficacy and safety of tisagenlecleucel in adult patients with Relapsed/Refractory follicular lymphoma: interim analysis of the Phase 2 Elara Trial. Blood. 2020;136(Supplement 1):1-3. doi:10.1182/blood-2020138983

34. Ghafouri S, Timmerman J, Larson S, Mead MD. Axicabtagene Ciloleucel CAR T-cell therapy for relapsed/refractory secondary CNS non-Hodgkin lymphoma: comparable outcomes and toxicities, but shorter remissions may warrant alternative consolidative strategies? Bone Marrow Transplant. 2020. doi:10.1038/s41409020-01099-4

35. Kaufman JL, Niesvizky R, Stadtmauer EA, et al. Phase I, multicentre, dose-escalation trial of monotherapy with milatuzumab (humanized anti-CD74 monoclonal antibody) in relapsed or refractory multiple myeloma. Br J Haematol. 2013;163(4): 478-486. doi:10.1111/bjh. 12565

36. Tai Y-T, Li X, Tong X, et al. Human anti-CD40 antagonist antibody triggers significant antitumor activity against human multiple myeloma. Cancer Res. 2005;65(13):5898-5906. doi:10.1158/ 0008-5472.CAN-04-4125

37. Stein H, Mason DY, Gerdes J, et al. The expression of the Hodgkin's disease associated antigen $\mathrm{Ki}-1$ in reactive and neoplastic lymphoid tissue: evidence that Reed-Sternberg cells and histiocytic malignancies are derived from activated lymphoid cells. Blood. 1985;66(4):848-858. doi:10.1182/blood.V66.4. 848.848

38. Ramos CA, Grover NS, Beaven AW, et al. Anti-CD30 CAR-T cell therapy in relapsed and refractory Hodgkin lymphoma. J Clin Oncol. 2020;38(32):3794-3804. doi:10.1200/ JCO.20.01342

39. Ramos CA, Ballard B, Zhang H, et al. Clinical and immunological responses after $\mathrm{CD} 30$-specific chimeric antigen receptor-redirected lymphocytes. J Clin Invest. 2017;127(9):3462-3471. doi:10.1172/ JCI94306

40. Gandhi UH, Cornell RF, Lakshman A, et al. Outcomes of patients with multiple myeloma refractory to CD38-targeted monoclonal antibody therapy. Leukemia. 2019;33(9):2266-2275. doi:10.1038/ s41375-019-0435-7

41. Tai Y-T, Anderson KC. Targeting B-cell maturation antigen in multiple myeloma. Immunotherapy. 2015;7(11):1187-1199. doi:10.2217/imt.15.77

42. Lin Y, Raje NS, Berdeja JG, et al. Idecabtagene Vicleucel (ide-cel, bb2121), a BCMA-directed CAR T cell therapy, in patients with relapsed and refractory multiple myeloma: updated results from Phase 1 CRB-401 Study. Blood. 2020;136 (Supplement 1):26-27.

43. Kansagra A, Lin Y, Berdeja JG, et al. Characterization of cytokine release syndrome in the KarMMa Study of Idecabtagene Vicleucel (ide-cel, bb2121) for relapsed and refractory multiple myeloma. Blood. 2020;136(Supplement 1):26-27. doi:10.1182/ blood-2020-134383

44. Alsina M, Shah N, Raje NS, et al. Updated results from the Phase I CRB-402 Study of Anti-Bcma CAR-T cell therapy bb21217 in patients with relapsed and refractory multiple myeloma: correlation of expansion and duration of response with $\mathrm{T}$ cell phenotypes. Blood. 2020;136(Supplement 1):25-26. doi:10.11 82/blood-2020-140410 
45. Finney OC, Yeri A, Mao P, et al. Molecular and phenotypic profiling of drug product and post-infusion samples from CRB-402, an ongoing: Phase I Clinical Study of bb21217 a BCMA-directed CAR T cell therapy. Blood. 2020;136 (Supplement 1):3-4. doi:10.1182/blood-2020-142426

46. Mailankody S, Jakubowiak AJ, Htut M, et al. Orvacabtagene autoleucel (orva-cel), a B-cell maturation antigen (BCMA)-directed CAR T cell therapy for patients (pts) with relapsed/refractory multiple myeloma (RRMM): update of the phase 1/2 EVOLVE study (NCT03430011). J Clin Oncol. 2020;38(15_suppl):8504. doi:10. 1200/JCO.2020.38.15_suppl.8504

47. Mailankody S, Htut $\bar{M}$, Lee KP, et al. JCARH125, Anti-BCMA CAR T-cell therapy for relapsed/refractory multiple myeloma: initial proof of concept results from a Phase 1/2 Multicenter Study (EVOLVE). Blood. 2018;132(Supplement 1):957. doi:10. 1182/blood-2018-99-113548

48. Madduri D, Berdeja JG, Usmani SZ, et al. CARTITUDE-1: Phase $1 \mathrm{~b} / 2$ Study of ciltacabtagene autoleucel, a B-cell maturation antigen-directed chimeric antigen receptor $\mathrm{T}$ cell therapy, in relapsed/refractory multiple myeloma. Blood. 2020;136 (Supplement 1):22-25. doi:10.1182/blood-2020-136307

49. Lin Y, Martin T, Cohen AD, et al. Cytokine release syndrome in patients with relapsed/refractory multiple myeloma treated with ciltacabtagene autoleucel in the Phase 1b/2 CARTITUDE-1 Study. Blood. 2020;136(Supplement 1):45-46. doi:10.1182/blood-2020-136360

50. Lee DW, Santomasso BD, Locke FL, et al. ASTCT consensus grading for cytokine release syndrome and neurologic toxicity associated with immune effector cells. Biol Blood Marrow Transplant. 2019;25(4):625-638. doi:10.1016/j.bbmt.2018.12.758

51. Wei J, Liu Y, Wang C, et al. The model of cytokine release syndrome in CAR T-cell treatment for B-cell non-Hodgkin lymphoma. Signal Transduct Target Ther. 2020;5(1):134. doi:10. 1038/s41392-020-00256-x

52. Park JH, Rivière I, Gonen M, et al. Long-term follow-up of CD19 CAR therapy in acute lymphoblastic leukemia. $N$ Engl J Med. 2018;378(5):449-459. doi:10.1056/NEJMoa1709919

53. Lee DW, Gardner R, Porter DL, et al. Current concepts in the diagnosis and management of cytokine release syndrome. Blood. 2014;124(2):188-195. doi:10.1182/blood-2014-05-552729

54. National Cancer Institute. Common Terminology Criteria for Adverse Events (CTCAE). Version 5.0. Available from: https:// ctep.cancer.gov/protocolDevelopment/electronic_applications/ctc. htm\#ctc_50. Accessed March 18, 2021.

55. Neelapu SS, Tummala S, Kebriaei $P$, et al. Chimeric antigen receptor T-cell therapy - assessment and management of toxicities. Nat Rev Clin Oncol. 2018;15(1):47-62. doi:10.1038/ nrclinonc. 2017.148

56. Gust J, Hay KA, Hanafi L-A, et al. Endothelial activation and blood-brain barrier disruption in neurotoxicity after adoptive immunotherapy with CD19 CAR-T cells. Cancer Discov. 2017;7 (12):1404-1419. doi:10.1158/2159-8290.CD-17-0698

57. Dholaria BR, Bachmeier CA, Locke F. Mechanisms and management of chimeric antigen receptor T-cell therapy-related toxicities. BioDrugs. 2019;33(1):45-60. doi:10.1007/s40259-018-0324-Z

58. McLellan AD, Ali Hosseini Rad SM. Chimeric antigen receptor $\mathrm{T}$ cell persistence and memory cell formation. Immunol Cell Biol. 2019;97(7):664-674. doi:10.1111/imcb.12254

59. Samur MK, Fulciniti M, Aktas samur A, et al. Biallelic loss of BCMA as a resistance mechanism to CAR T cell therapy in a patient with multiple myeloma. Nat Commun. 2021;12(1):868. doi:10.1038/s41467-021-21177-5

60. Schmidts A, Ormhøj M, Choi BD, et al. Rational design of a trimeric APRIL-based CAR-binding domain enables efficient targeting of multiple myeloma. Blood Adv. 2019;3 (21):3248-3260. doi:10.1182/bloodadvances.2019000703
61. Borchmann P, Jühling A, Gödel P, et al. Phase I Trial of MB-CART2019.1, a Novel CD20 and CD19 targeting tandem chimeric antigen receptor, in patients with relapsed or refractory B-cell non-Hodgkin lymphoma. Blood. 2020;136(Supplement 1):48. doi:10.1182/blood-2020-136067

62. Hu Y, Zhang Y, Zhao H, et al. CD19/CD22 dual-targeted chimeric antigen receptor T-cell therapy for relapsed/refractory aggressive B-cell lymphoma: a Safety and Efficacy Study. Blood. 2020;136 (Supplement 1):34. doi:10.1182/blood-2020-143239

63. Zhang $\mathrm{R}, \mathrm{Li} \mathrm{Y}, \mathrm{Tu} \mathrm{S}$, et al. Improved safety and efficacy of a multi-target chimeric antigen receptor modified $\mathrm{T}$ Cell therapy (4SCAR2.0) against relapsed or refractory lymphomas. Blood. 2020;136(Supplement 1):47. doi:10.1182/blood-2020-141515

64. Osborne W, Marzolini M, Tholouli E, et al. Phase I Alexander study of AUTO3, the first CD19/22 dual targeting CAR T cell therapy, with pembrolizumab in patients with relapsed/refractory (r/r) DLBCL. J Clin Oncol. 2020;38(15_suppl):8001. doi:10.12 00/JCO.2020.38.15 suppl.8001

65. Jamal S, Picker LJ, Aquino DB, et al. Immunophenotypic analysis of peripheral T-cell neoplasms. A multiparameter flow cytometric approach. Am J Clin Pathol. 2001;116(4):512-526. doi:10.1309/QF6N-VAQW-N74H-4JE2

66. Chun I, Kim KH, Chiang Y-H, et al. CRISPR-Cas9 Knock out of CD5 enhances the anti-tumor activity of chimeric antigen receptor T cells. Blood. 2020;136(Supplement 1):51-52. doi:10.1182/blood-2020136860

67. Themeli M, Kloss CC, Ciriello G, et al. Generation of tumor-targeted human $\mathrm{T}$ lymphocytes from induced pluripotent stem cells for cancer therapy. Nat Biotechnol. 2013;31 (10):928-933. doi:10.1038/nbt.2678

68. Carpenter RO, Evbuomwan MO, Pittaluga S, et al. B-cell maturation antigen is a promising target for adoptive T-cell therapy of multiple myeloma. Clin Cancer Res. 2013;19(8):2048-2060. doi:10.1158/1078-0432.CCR-12-2422

69. Laâbi Y, Gras MP, Carbonnel F, et al. A new gene, BCM, on chromosome 16 is fused to the interleukin 2 gene by a $\mathrm{t}(4 ; 16)(\mathrm{q} 26$; p13) translocation in a malignant $\mathrm{T}$ cell lymphoma. EMBO J. 1992;11(11):3897-3904. doi:10.1002/j.1460-2075.1992.tb05482.x

70. Tai Y-T, Dillon M, Song W, et al. Anti-CS1 humanized monoclonal antibody HuLuc63 inhibits myeloma cell adhesion and induces antibody-dependent cellular cytotoxicity in the bone marrow milieu. Blood. 2008;112(4):1329-1337. doi:10.1182/blood2007-08-107292

71. Chillemi A, Zaccarello G, Quarona V, et al. Anti-CD38 antibody therapy: windows of opportunity yielded by the functional characteristics of the target molecule. Mol Med. 2013;19(1):99-108. doi:10.2119/molmed.2013.00009

72. Stevenson FK, Bell AJ, Cusack R, et al. Preliminary studies for an immunotherapeutic approach to the treatment of human myeloma using chimeric anti-CD38 antibody. Blood. 1991;77 (5):1071-1079. doi:10.1182/blood.V77.5.1071.1071

73. Malavasi F, Deaglio S, Funaro A, et al. Evolution and function of the ADP ribosyl cyclase/CD38 gene family in physiology and pathology. Physiol Rev. 2008;88(3):841-886. doi:10.1152/physrev.00035.2007

74. Wijdenes J, Vooijs WC, Clément C, et al. A plasmocyte selective monoclonal antibody (B-B4) recognizes syndecan-1. $\mathrm{Br}$ $J \quad$ Haematol. 1996;94(2):318-323. doi:10.1046/j.13652141.1996.d01-1811.x

75. Van Camp B, Durie BG, Spier C, et al. Plasma cells in multiple myeloma express a natural killer cell-associated antigen: CD56 (NKH-1; Leu-19). Blood. 1990;76(2):377-382. doi:10.1182/blood. V76.2.377.377

76. Drach J, Gattringer C, Huber H. Multiple myeloma with coexpression of myeloid and natural killer cell antigens [letter]. Blood. 1990;76(1):265-266. doi:10.1182/blood.V76.1.265.265 
77. Mechtersheimer G, Staudter M, Möller P. Expression of the natural killer (NK) cell-associated antigen CD56(Leu-19), which is identical to the $140-\mathrm{kDa}$ isoform of N-CAM, in neural and skeletal muscle cells and tumors derived therefrom. Ann N Y Acad Sci. 1992;650:311-316. doi:10.1111/j.1749-6632.1992.tb49143.x

78. Burton JD, Ely S, Reddy PK, et al. CD74 is expressed by multiple myeloma and is a promising target for therapy. Clin Cancer Res. 2004;10(19):6606-6611. doi:10.1158/1078-0432.CCR-04-0182

79. Bensinger W, Maziarz RT, Jagannath S, et al. A phase 1 study of lucatumumab, a fully human anti-CD40 antagonist monoclonal antibody administered intravenously to patients with relapsed or refractory multiple myeloma. Br J Haematol. 2012;159(1):58-66. doi:10.1111/j.1365-2141.2012.09251.x

80. Matsui W, Huff CA, Wang Q, et al. Characterization of clonogenic multiple myeloma cells. Blood. 2004;103(6):2332-2336. doi:10.1182/blood-2003-09-3064

81. Ramos CA, Savoldo B, Torrano V, et al. Clinical responses with $\mathrm{T}$ lymphocytes targeting malignancy-associated $\kappa$ light chains. J Clin Invest. 2016;126(7):2588-2596. doi:10.1172/JCI86000

82. Peinert S, Prince HM, Guru PM, et al. Gene-modified T cells as immunotherapy for multiple myeloma and acute myeloid leukemia expressing the Lewis Y antigen. Gene Ther. 2010;17 (5):678-686. doi:10.1038/gt.2010.21

83. Condomines M, Hose D, Raynaud P, et al. Cancer/testis genes in multiple myeloma: expression patterns and prognosis value determined by microarray analysis. J Immunol. 2007;178(5):33 07-3315. doi:10.4049/jimmunol.178.5.3307

84. Rapoport AP, Stadtmauer EA, Binder-Scholl GK, et al. NY-ESO -1-specific TCR-engineered $\mathrm{T}$ cells mediate sustained antigen-specific antitumor effects in myeloma. Nat Med. 2015;21(8):914-921. doi:10.1038/nm.3910

85. Garfall AL, Maus MV, Hwang W-T, et al. Chimeric antigen receptor T cells against CD19 for multiple myeloma. $N$ Engl $J$ Med. 2015;373(11):1040-1047. doi:10.1056/NEJMoa1504542

86. Venniyil Radhakrishnan S, Luetkens T, Yousef S, et al. Chimeric Antigen Receptor (CAR) T cells specific for CD229: a potentially curative approach for multiple myeloma. Blood. 2017;130(Suppl 1).

87. Yousef S, Kovacsovics-Bankowski M, Salama ME, et al. CD229 is expressed on the surface of plasma cells carrying an aberrant phenotype and chemotherapy-resistant precursor cells in multiple myeloma. Hum Vaccin Immunother. 2015;11(7):1606-1611. doi:10.1080/21645515.2015.1046658

88. Baumeister SH, Murad J, Werner L, et al. Phase I trial of autologous CAR T cells targeting NKG2D ligands in patients with AML/MDS and multiple myeloma. Cancer Immunol Res. 2019;7 (1):100-112. doi:10.1158/2326-6066.CIR-18-0307

89. Dillon SR, Harder B, Lewis KB, et al. B-lymphocyte stimulator/a proliferation-inducing ligand heterotrimers are elevated in the sera of patients with autoimmune disease and are neutralized by atacicept and B-cell maturation antigen-immunoglobulin. Arthritis Res Ther. 2010;12(2):R48. doi:10.1186/ar2959

90. Nagatani K, Itoh K, Nakajima K, et al. Rheumatoid arthritis fibroblast-like synoviocytes express BCMA and are stimulated by APRIL. Arthritis Rheum. 2007;56(11):3554-3563. doi:10.10 02/art.22929

91. Smith EL, Harrington K, Staehr M, et al. GPRC5D is a target for the immunotherapy of multiple myeloma with rationally designed CAR T cells. Sci Transl Med. 2019;11(485):eaau7746. doi:10.11 26/scitranslmed.aau 7746

92. Li J, Stagg NJ, Johnston J, et al. Membrane-proximal epitope facilitates efficient $\mathrm{T}$ cell synapse formation by Anti-FcRH5/CD3 and is a requirement for myeloma cell killing. Cancer Cell. 2017;31(3):383-395. doi:10.1016/j.ccell.2017.02.001
93. Ding S, Mao X, Cao Y, et al. Targeting CD79b for chimeric antigen receptor T-cell therapy of B-cell lymphomas. Target Oncol. 2020;15(3):365-375. doi:10.1007/s11523-020-00729-7

94. Ormhøj M, Scarfò I, Cabral ML, et al. Chimeric antigen receptor $\mathrm{T}$ cells targeting CD79b show efficacy in lymphoma with or without cotargeting CD19. Clin Cancer Res. 2019;25 (23):7046-7057. doi:10.1158/1078-0432.CCR-19-1337

95. Loken MR, Shah VO, Dattilio KL, Civin CI. Flow cytometric analysis of human bone marrow. II. Normal B lymphocyte development. Blood. 1987;70(5):1316-1324. doi:10.1182/blood. V70.5.1316.1316

96. Mason DY, Stein H, Gerdes J, et al. Value of monoclonal anti-CD22 (p135) antibodies for the detection of normal and neoplastic B lymphoid cells. Blood. 1987;69(3):836-840. doi:10. 1182/blood.V69.3.836.836

97. Broome HE, Rassenti LZ, Wang H-Y, Meyer LM, Kipps TJ. ROR1 is expressed on hematogones (non-neoplastic human B-lymphocyte precursors) and a minority of precursor-B acute lymphoblastic leukemia. Leuk Res. 2011;35(10):1390-1394. doi:10.1016/j.leukres.2011.06.021

98. Barna G, Mihalik R, Timár B, et al. ROR1 expression is not a unique marker of CLL. Hematol Oncol. 2011;29(1):17-21. doi:10.1002/hon.948

99. Bertrand P, Maingonnat C, Penther D, et al. The costimulatory molecule CD70 is regulated by distinct molecular mechanisms and is associated with overall survival in diffuse large B-cell lymphoma. Genes Chromosomes Cancer. 2013;52(8):764-774. doi:10.1002/gcc. 22072

100. Karube K, Ohshima K, Tsuchiya $\mathrm{T}$, et al. Non-B, non-T neoplasms with lymphoblast morphology: further clarification and classification. Am J Surg Pathol. 2003;27(10):13 66-1374. doi:10.1097/00000478-200310000-00009

101. Suzuki R, Ohtake S, Takeuchi J, et al. The clinical characteristics of CD7+ CD56+ acute myeloid leukemias other than M0. Int J Hematol. 2010;91(2):303-309. doi:10.1007/s12185-010-0492-1

102. Bobrowicz M, Kubacz M, Slusarczyk A, Winiarska M. CD37 in B cell derived tumors - more than just a docking point for monoclonal antibodies. Int J Mol Sci. 2020;21(24):9531. doi:10.3390/ ijms21249531

103. Engleman EG, Warnke R, Fox RI, et al. Studies of a human $\mathrm{T}$ lymphocyte antigen recognized by a monoclonal antibody. Proc Natl Acad Sci. 1981;78(3):1791-1795. doi:10.1073/pnas.78. 3.1791

104. Went P, Agostinelli C, Gallamini A, et al. Marker expression in peripheral T-cell lymphoma: a proposed clinical-pathologic prognostic score. J Clin Oncol. 2006;24(16):2472-2479. doi:10.1200/ JCO.2005.03.6327

105. Maciocia PM, Wawrzyniecka PA, Philip B, et al. Targeting the $\mathrm{T}$ cell receptor $\beta$-chain constant region for immunotherapy of T cell malignancies. Nat Med. 2017;23(12):1416-1423. doi:10. 1038/nm.4444

106. Weber EW, Lynn RC, Sotillo E, et al. Pharmacologic control of CAR-T cell function using dasatinib. Blood Adv. 2019;3 (5):711-717. doi:10.1182/bloodadvances.2018028720

107. Costello CL, Cohen AD, Patel KK, et al. Phase 1/2 Study of the Safety and Response of P-BCMA-101 CAR-T cells in Patients with Relapsed/Refractory (r/r) Multiple Myeloma (MM) (PRIME) with novel therapeutic strategies. Blood. 2020;136 (Supplement 1):29-30. doi:10.1182/blood-2020-142695 


\section{Publish your work in this journal}

OncoTargets and Therapy is an international, peer-reviewed, open access journal focusing on the pathological basis of all cancers, potential targets for therapy and treatment protocols employed to improve the management of cancer patients. The journal also focuses on the impact of management programs and new therapeutic

Submit your manuscript here: https://www.dovepress.com/oncotargets-and-therapy-journal agents and protocols on patient perspectives such as quality of life, adherence and satisfaction. The manuscript management system is completely online and includes a very quick and fair peer-review system, which is all easy to use. Visit http://www.dovepress.com/ testimonials.php to read real quotes from published authors. 